\title{
ДОСТОЙНАЯ РАБОТА И ЭКОНОМИЧЕСКИЙ РОСТ
}

\section{Г.А. Василевич}

Юридический факультет БГУ, кафедра конституционного права, ул. Ленинградская, 8, 220030, г. Минск, Беларусь, Gregory_111@mail.ru

В статье уделено внимание взаимовлиянию права на достойный труд и рост экономического благополучия. Раскрывается понятие права на «достойный труд». Вносятся предложения по совершенствованию законодательства (о внесении изменений в Конституцию в части закрепления права на достойный труд, установления дополнительных гарантий для молодежи, молодых специалистов, а также об утверждении Правительством Концепции обеспечения занятости и достойного труда, рассчитанной до 2030 года, и др.).

Ключевые слова: достойный труд; заработная плата; право на труд; экономический рост.

Производительная занятость и «достойная работа» являются важнейшими элементами достижения общего благополучия. В юридической литературе понятие «достойный труд» рассматривается как высокоэффективный труд в безопасных производственных условиях, когда человек получает удовлетворение, имеет возможность в полной мере проявить свои способности, навыки и мастерство. Это труд с достойной оплатой и справедливым распределением плодов прогресса, труд, когда права трудящихся защищены и они активно участвуют в деятельности организации, внося максимально возможный вклад в общее благополучие [1, с. 16].

Концепция достойного труда обоснована Международной организацией труда (далее - МОТ). В МОТ в качестве признаков достойного труда называют «продуктивную деятельность или производительный труд, способный обеспечить конкурентоспособность страны; достойный и справедливый доход для работников; безопасность на рабочем месте; социальную защиту (от безработицы, в случае беременности, необходимости ухода за ребенком, временной нетрудоспособности, пенсионное обеспечение); перспективы для индивидуального развития и социальной интеграции; активное участие в принятии управленческих решений (через профсоюзы и ассоциации предпринимателей); равные стартовые позиции и возможности для обоих полов» [2, с.5].

Достойный труд связан с достойной занятостью для мужчин и женщин [3]. Сейчас происходят изменения в структуре занятости. На это влияют в современных условиях не только глобализация, но и пандемия коронавируса COVID-19, а также широкое внедрение информационных технологий.

Проблемная точка - эффективная занятость. Уровень безработицы, официально зарегистрированной, и безработицы, исчисляемой по критериям МОТ, различаются. Поэтому не только размер пособия по безработице, который, с одной стороны, должен играть стимулирующую роль, а с другой, обеспечивать приемлемый уровень материальной поддержки человека, оказавшегося в сложных условиях при отсутствии работы, но и структура занятости - все это важные составляющие в сфере обеспечения права на достойный труд.

Одним из составляющих характеристики достойного труда является уровень заработной платы [4, с.243]. Конечно, ее размер зависит от имеющихся у государства ресурсов. Но эффективность труда зависит от уровня заработной платы, как и размер 
заработной платы находится в прямой зависимости от качества (эффективности) труда.

Важна организующая роль органов государственной власти и, прежде всего, органов исполнительной власти. То есть перед ними в новых условиях, с учетом развития и расширяющегося внедрения информационных технологий, возникают новые задачи, которые требуют своего решения. К ним можно отнести прогнозирование потребности в специалистах как рабочих профессий, так и управленцев, оценка динамики занятости, старения населения, развития новых профессий и др.

Актуальной и дискуссионной в последние годы является тема сокращения числа рабочих дней в течение недели. Вносятся предложения о переходе на четырехдневную рабочую неделю с сохранением нынешнего количества рабочих часов в неделю. Некоторые предприниматели в западных странах уже внедрили такую практику и это, по их мнению, дает экономический эффект. При этом важно, чтобы не снижалась заработная плата. Высказываются аргументы как в пользу перехода на четырехдневную рабочую неделю, так и против.

На наш взгляд, идея имеет больше положительных сторон. Но, конечно, она должна быть основательно изучена. Можно было бы в порядке эксперимента перевести на такой режим отдельные организации и оценить последствия с точки зрения производительности труда, а также преимуществ, которые люди получают в области досуга, проведения большего времени с детьми и их воспитанием, реализацией общественных инициатив.

С учетом изложенного и в связи с намеченной модернизацией конституционного текста можно было в Основном Законе (ст. 41) закрепить новое положение, а именно: о праве граждан на достойный труд. Это расширило бы содержание права на труд, которое сейчас провозглашено в Конституции, и содействовало бы мобилизации усилий институтов власти в указанном направлении, отвечало бы уже давно признаваемому в конституционном праве другому, по сути интегральному праву, праву на хорошее управление.

В процессе подготовки изменений в Конституцию Республики Беларусь особое внимание в ее тексте следовало бы уделить молодежи.

В ст. 32 Конституции Республики Беларусь предлагаем подчеркнуть, что государство проявляет особую заботу о молодежи, оказывает помощь в раскрытии ее талантов, развитии культурных, научных, творческих и физических способностей, поощряет их участие в волонтерской деятельности, общественной жизни.

Молодежи гарантируется право на ее духовное, нравственное и физическое развитие.

Государство создает необходимые условия для свободного и эффективного участия молодежи в политическом, социальном, экономическом и культурном развитии. Такого рода изменения станут важным ориентиром для нормотворческих и правоприменительных органов, организаций и граждан.

Для того, чтобы у молодежи были наилучшие возможности по переходу на достойную работу, необходимы инвестиции в образование и профессиональную подготовку наивысшего возможного качества.

В ряде конституций предусматривается минимальный процент ВВП, который должен быть направлен на образование и здравоохранение. Сохранение и приумножение здоровья населения - это также источники эффективного (производительного) труда, а также экономии государственных средств. 
Практика свидетельствует, что недостаточно целенаправленно проводится подготовка за счет бюджетных средств молодых специалистов, в которых нуждается экономическая и социальная сфера нашей страны. Конечно, нам известны нарекания относительно обязанности молодых специалистов работать в тех организациях, куда они направлены вузовской комиссией по распределению. Это нельзя расценивать как принудительный труд. В то же время, в таких странах, как Испания или Португалия, где очень высокий уровень безработицы среди молодежи, выпускники были бы счастливы получению первого рабочего места.

В белорусских реалиях пока не обеспечен баланс потребностей государственного сектора и числа выпускников, обучавшихся за счет бюджета. Кроме того, много примеров, когда выпускникам высших и средних специальных учебных заведений по месту их распределения не создаются надлежащие условия для работы и проживания. Вот здесь поле деятельности для соответствующих министерств. Планировать прием молодых специалистов и создавать условия для сохранения у них желания оставаться и после «отработки» по месту распределения - важная государственная задача, выполнение которой даст экономический эффект. Ее следует решать заблаговременно, хотя бы за полгода, год до приезда молодого специалиста.

Полагаем, что в условиях Республики Беларусь следовало бы разработать и принять на уровне Правительства Концепцию обеспечения занятости и достойного труда, рассчитанную до 2030 года. Уже сейчас необходимо предвидеть возможные изменения в структуре занятости, определить оптимальную численность работников и управленческого персонала, сосредоточить внимание на развитии перспективных отраслей, направлениях использования высвобождаемых ресурсов, подготовку специалистов в учебных заведениях, взвесить соответствующие потребности. Министерству образования Республики Беларусь совместно с Министерством труда и социальной защиты Республики Беларусь.

На наш взгляд, можно было бы провести анализ работы выпускников средних специальных и высших учебных заведений по специальности. Отдельно стоит вопрос о выпускниках магистратуры. При направлении их работу (не только в научные и образовательные учреждения) можно было бы определить перечень должностей, для занятия которых необходимо окончание магистратуры либо магистрант при прочих равных условиях должен пользоваться преимуществом при приеме на соответствующую должность.

Заметим, что оптимальное законодательство само по себе может дать экономический эффект [5]. Рациональное правовое регулирование, но с соблюдением правовых стандартов, обеспечивает экономию ресурсов (материальных и социальных), обеспечивает устойчивое развитие общества и государства.

В связи с подготовкой изменений в Конституцию и их одобрением полезно было бы, на наш взгляд, издание политико-правового программного документа (возможно директивы Главы государства), провозглашающего новую экономическую и правовую политику (НЭПП), широко охватывающего в концептуальном плане основные направления деятельности органов государственной власти в экономической и социальной областях.

В качестве возможного варианта может быть принятие нового программного закона об основных направлениях внутренней и внешней политики. Его проект можно было представить для обсуждения в русле намеченных конституционных изменений либо акцентировать внимание на его разработке. 


\section{Библиографические ссылки}

1. Костин Л.А. Достойный труд в XXI веке // Достойный труд - высшая цель и жизненная необходимость: круглый стол «Достойный труд в XXI веке», 25 нояб. 2005 г., Юбилейные Ломоносовские чтения, посвященные 250-летию МГУ им. М.В. Ломоносова. М.: ТЕИС, 2005.

2. Барет-Рид П. Неотъемлемые признаки достойного труда // Человек и труд. 2003. №3. C.4-10.

3. Василевич Г. А. Обеспечение занятости - конституционная обязанность социального государства. Право и экономика: междисциплинарные подходы в науке и образовании. IV Московский юридический форум, XII Междунар. Науч.-практ. Конф. (Кутафинские чтения): материалы конференции 4 частях. Ч. 1. М.: РГ-Пресс, 2017. С. 92-96.

4. Томашевский К.Л. Право на достойный труд: международно-правовая концепция и опыт реализации в Беларуси // За права трудящихся! Эффективная защита трудовых прав: проблемы теории и практики: материалы третьей Междунар. науч.-практ. конф. (г.Екатеринбург, 7-8 дек. 2017 г.) / УрГЮУ. Екатеринбург, 2017. С.238-243.

5. Василевич Г.А., Василевич, С.Г. Юридическое прогнозирование и экономический анализ права - важнейшие потребности современной нормотворческой деятельности. Проблемы управления. 2017. №4. С. 36-42.

\section{НЕКОТОРЫЕ ВОПРОСЫ СОВЕРШЕНСТВОВАНИЯ ИСПОЛНИТЕЛЬНОГО ПРОИЗВОДСТВА В РЕСПУБЛИКЕ БЕЛАРУСЬ}

\section{М.Г. Ващебрович}

Институт управленческих кадров Академии управления при Президенте Республики Беларусь, ул. Московская, 17, 220007, г. Минск, Республика Беларусь,8765492@таіl.ru

В статье рассматриваются некоторые вопросы повышения эффективности работы судебных исполнителей. Предлагается разработка квалификационных требований к должности судебного исполнителя. Также в работе обосновывается необходимость в разработке и законодательном закреплении практико-ориентированной программы послевузовской подготовки и сдачи квалификационного экзамена лицам претендующими на должность судебного исполнителя. Также затрагиваются вопросы внедрения института частных судебных исполнителей в Республике Беларусь.

Ключевые слова: судебный исполнитель; квалификационные требования; институт частных судебных исполнителей; реестр судебных исполнителей; квалификационный экзамен; профессиональные качества.

Наиболее важным представляется изучение практики принудительного исполнения зарубежных стран, можно сказать, что добиться своевременного и добровольного исполнения судебных постановлений и иных юрисдикционных актов должниками без применения мер принуждения не удавалось ни одному государству в мире.

В настоящее время одной из главных проблем является высокая нагрузка, возлагающаяся на судебных исполнителей. Например, в первом полугодии 2020 года органами принудительного исполнения возбуждено 979 тысяч исполнительных производств, в 2019 году на исполнение поступило 2,9 млн. исполнительных документов, в 2018 году - уже 2,7 млн. Но, показатели реального исполнения исполнительных 